\title{
Spatiotemporal Variation of Frost within Growing Periods
}

\author{
Mokhele Edmond Moeletsi ${ }^{1,2}$ and Mphethe Isaac Tongwane ${ }^{1}$ \\ ${ }^{1}$ Agricultural Research Council, Institute for Soil, Climate and Water, Private Bag X79, Pretoria 0001, South Africa \\ ${ }^{2}$ Risks and Vulnerability Assessment Centre, University of Limpopo, Private Bag X1106, Sovenga 0727, South Africa \\ Correspondence should be addressed to Mokhele Edmond Moeletsi; moeletsim@arc.agric.za
}

Received 22 February 2017; Revised 13 May 2017; Accepted 4 June 2017; Published 26 July 2017

Academic Editor: Anthony R. Lupo

Copyright ( 2017 Mokhele Edmond Moeletsi and Mphethe Isaac Tongwane. This is an open access article distributed under the Creative Commons Attribution License, which permits unrestricted use, distribution, and reproduction in any medium, provided the original work is properly cited.

\begin{abstract}
Frost is one of the devastating agroclimatological hazards affecting crop production in the Free State Province of South Africa. In this study, frost $\left(0^{\circ} \mathrm{C}\right.$ threshold) probabilities within different growing periods starting from the first dekad of October to the third dekad of February for a 100-day, 120-day, and 140-day crop were determined. The data used in the investigation was daily minimum temperature obtained from 55 weather stations located in and around the Free State Province with data from 1950 to 2010. The results show high spatial and temporal variability of frost within the different growing periods. The western, central, northern, and northwestern parts of the province have the longest planting window for all the growing lengths from mid-October to mid-January. The eastern, northeastern, southern, and southeastern parts of Free State have the highest frost risk with shortened planting window mostly from the first dekad of November to the second dekad of December. Thus, careful consideration of frost incidences is important for successful crop production in this area.
\end{abstract}

\section{Introduction}

Weather extremes affecting agriculture are a major concern in recent times and are projected to increase in intensity in the future [1]. Frost is among the agroclimate risks that are detrimental to crop and fruit production in most places of the mid and high latitudes [2,3]. Frost normally occurs when air temperature drops to or below $0^{\circ} \mathrm{C}$ resulting in ice formation on plant material and soil [4]. The rate of temperature reduction during the night is influenced by, among other factors, wind speed, atmospheric water vapour pressure, atmospheric stability, precipitation, sky temperature, cloud cover, and local topographical features $[4,5]$.

In temperate and subtropical areas like the Free State, frost is one of the main weather disasters that cause damage to crops [6-8]. The extent of frost damage on a crop is dependent on plant type and variety, rate of temperature decrease, cloud and wind conditions during the freeze, soil type and water content, duration of frost, and crop growth stage [9-11]. Many plants are more resistant to frost during their early development stage and less frost resistant during the latter stages of the growth and development $[10,12]$.
Thus, farmers should manage their farms in such a way that the vulnerable stages of crop development such as flowering and grain filling do not coincide with period of high frost incidences [13]. The severity of frost damage is dependent on the duration and extent of below freezing temperatures [14]. Frost damage can reduce crop yield and quality and thus frost risk has to be considered in planning to ensure proper selection of crop varieties and planting schedule [15]. Weak frost can cause damage to sensitive plants and fruit trees, and moderate frost causes damage to semihardy plants and trees, while severe/hard frost usually damages all the crops and fruit trees [16]. Different species have different tolerances to frost: fruit trees like apples and pears are said to be more frost resistant than peaches and apricots, while wheat is generally more frost-tolerant than maize and sorghum [17]. In fruits, the quality of the fruit is strongly affected by light frost while severe frost has a major impact on the final harvest $[7,18]$.

Daily minimum temperatures measured at Stevenson screen level (height of $1.5 \mathrm{~m}$ above the ground) are normally used to assess the occurrence of frost in most places where ground or canopy level measurements are not recorded and the most common threshold value is temperature of $0^{\circ} \mathrm{C}$ or 


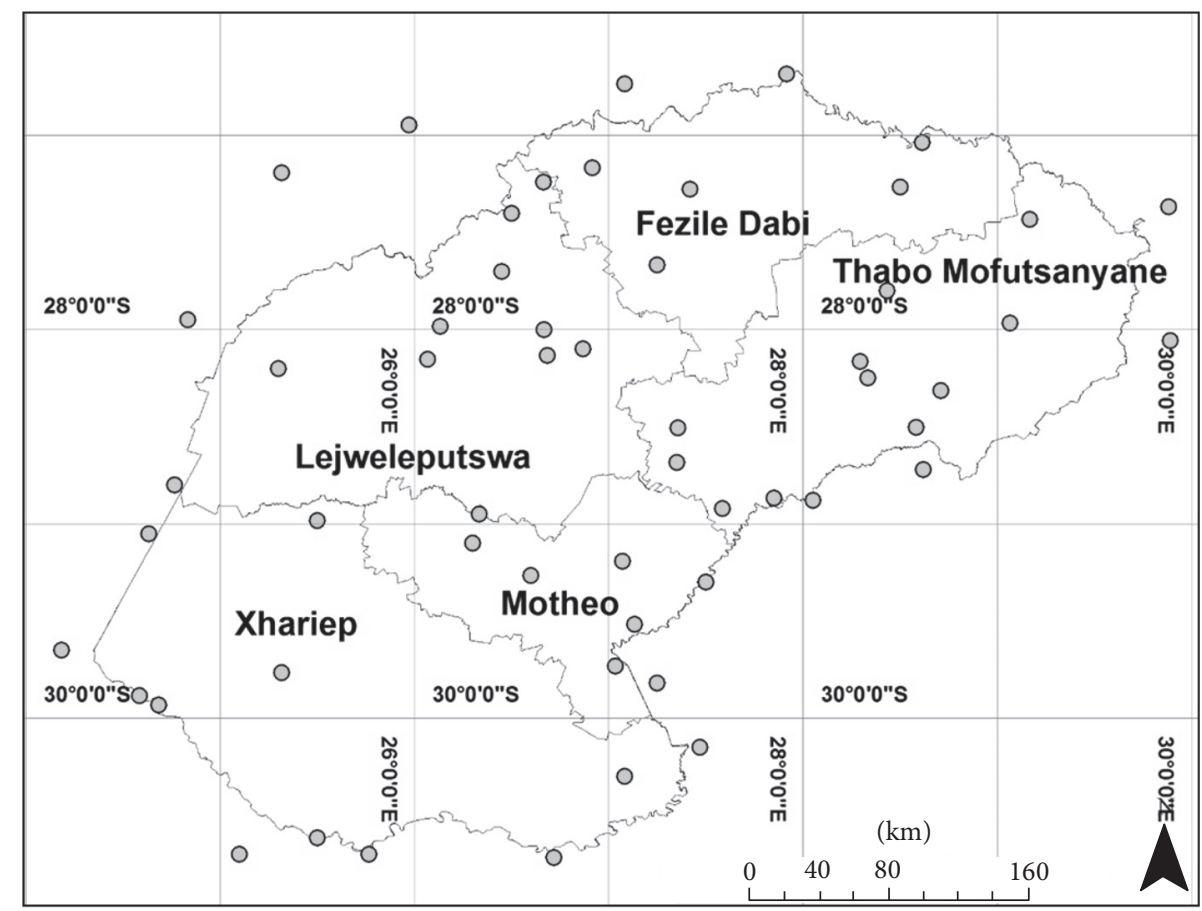

Figure 1: Spatial distribution of climate stations located in and around the Free State Province of South Africa that were used in frost risk analysis.

less $[4,19]$. In this study, frost risk in the Free State Province of South Africa was determined during different planting dates starting from September to February for 100-day, 120day, and 140-day growing periods representing short season, medium season, and long season crop varieties. The objective was to investigate the effect of frost on the planting periods of different crop cultivars as well as its spatial and temporal variability in the Free State Province.

\section{Data and Methods}

2.1. Study Area. The risk of frost varies greatly in the Free State Province due to the contrasting topography and geographical aspect [8]. The topography of the province is diverse, with altitudes of $<1200 \mathrm{~m}$ in the south and $3000 \mathrm{~m}$ in the eastern parts [20]. The eastern Free State shares a border with the northern part of the Kingdom of Lesotho where the highest region of the Drakensberg escarpment is located. In the eastern Free State, dry and windy atmospheric conditions that increase atmospheric water vapour pressure deficit reach their highest levels during September and October [21]. These conditions, coupled with predominant anticyclonic environment, favour radiative frost which is the main frost type in this region. Onset of rains that start the summer cropping season occurs during the last dekad of September in eastern and northeastern parts of the province, during the second dekad of October to the second dekad of November in the central, northern, and southern parts, and in December in the west [22].
2.2. Data. The daily minimum temperature dataset from 1950 to 2010 was used in the analysis for determination of frost risk assessment in the Free State Province. The data first went through a quality check as outlined in Tongwane et al. [21] and erroneous data were removed. Where necessary the data gaps were patched using the regression method that utilizes data from neighbour stations [23]. The data used in the analysis was obtained from the Agricultural Research Council, Lesotho Meteorological Services, and South African Weather Service. The stations used were chosen in the Free State, as well as in neighbouring provinces and Lesotho, with at least 20 years of data records and with less than $30 \%$ missing data. Figure 1 shows the spatial distribution of the stations that were used in the study while Tables 1 and 2 show geographical information for stations in the Free State and surrounding provinces. A total of 36 weather stations were selected in the Free State and 19 weather stations were selected in the surrounding provinces including Lesotho.

2.3. Determination of Frost within Growing Periods. All the data was arranged according to the agricultural season from July to June of the following year. In this study a frost day is considered as any day in which daily minimum temperature is equal to or less than $0^{\circ} \mathrm{C}$. Organization of the data was done on a dekadal (10-day) basis. The first 10 days of the month are grouped as the first dekad of the month, the second 10 days (11-20) as the second dekad, and the final days (21 to 28, 29,30 , or 31 depending on the month and year) as the last dekad of the month. The study investigated frost occurrence 
TABLE 1: Free State Province climate stations used in the frost risk analysis.

\begin{tabular}{|c|c|c|c|}
\hline Station & Latitude & Longitude & Altitude (m) \\
\hline Bethlehem & -28.2500 & 28.3333 & 1680 \\
\hline Bethlehem-ARC & -28.1626 & 28.2953 & 1631 \\
\hline Bleskop & -29.8833 & 24.5833 & 1145 \\
\hline Bloemfontein-Hertzog & -29.1000 & 26.3000 & 1351 \\
\hline Bothaville-Balkfontein & -27.4000 & 26.5000 & 1280 \\
\hline Bothaville-Nampo & -27.2389 & 26.6638 & 1300 \\
\hline Bultfontein & -28.1513 & 26.0672 & 1306 \\
\hline Clocolan & -28.9211 & 27.5841 & 1602 \\
\hline Fauresmith & -29.7700 & 25.3200 & 1522 \\
\hline Ficksburg & -28.8667 & 27.8500 & 1829 \\
\hline Frankfort & -27.2667 & 28.5000 & 1502 \\
\hline Gariep Dam & -30.6167 & 25.5000 & 1324 \\
\hline Glen College & -28.9500 & 26.3333 & 1304 \\
\hline Golden Gate & -28.5037 & 28.5837 & 1846 \\
\hline Hertzogville & -28.2000 & 25.3000 & 1326 \\
\hline Hobhouse & -29.5167 & 27.1333 & 1448 \\
\hline Kestell & -28.3141 & 28.7086 & 1692 \\
\hline Koppies & -27.2778 & 27.4180 & 1401 \\
\hline Kroonstad & -27.6667 & 27.2500 & 1348 \\
\hline Marquard & -28.5044 & 27.3563 & 1447 \\
\hline Oukraal & -29.9333 & 24.6833 & 1143 \\
\hline Petrusburg & -28.9833 & 25.5000 & 1219 \\
\hline Plessis Draai & -27.9833 & 26.1333 & 1249 \\
\hline Reitz & -27.8000 & 28.4333 & 1615 \\
\hline Rietpan & -27.1667 & 26.9167 & 1321 \\
\hline Rustfontein Dam & -29.2667 & 26.6000 & 1382 \\
\hline Tweespruit & -29.1936 & 27.0696 & 1567 \\
\hline Villiers & -27.0368 & 28.6149 & 1493 \\
\hline Virginia & -28.1000 & 26.8667 & 1335 \\
\hline Vrede & -27.4333 & 29.1667 & 1670 \\
\hline Warden & -27.9700 & 29.0700 & 1770 \\
\hline Welkom & -28.1333 & 26.6833 & 1295 \\
\hline Welkom-AER & -28.0000 & 26.6667 & 1338 \\
\hline Wepener & -29.7333 & 27.0333 & 1438 \\
\hline Wesselsbron & -27.7000 & 26.4500 & 1325 \\
\hline Zastron & -30.3000 & 27.0830 & 1661 \\
\hline
\end{tabular}

on three different length growing periods: 100 days, 120 days, and 140 days. Starting from the 1st dekad of September, when the rainfall season starts in some parts of the Free State [22], to the last dekad of February, the occurrence of frost $\left(0^{\circ} \mathrm{C}\right)$ during the three growing periods was determined using daily minimum temperature from 1950 to 2010.

2.4. Spatial Variation of Frost Probabilities within Growing Periods. For each station, the frequency of frost was determined from an array of planting dates starting from the first dekad of September to the last dekad of February for 100day, 120-day, and 140-day growing periods in all the years. Absolute probability of a frost occurrence in the season was obtained as the ratio of number of years with frost over the total number of years for each presumed planting dekad and growing period length shown in (1). Interpolation of the frost indices was done using the inverse distance weighting model imbedded in ArcGIS 9.3 software.

$$
\mathrm{FP}_{i j}=\frac{C_{i j}}{T_{i j}},
$$

where $i$ is the growing period length (100 days, 120 days, or 140 days); $j$ is the planting dekad ranging from 1st dekad of September to 1st dekad of January; $\mathrm{FP}_{i j}$ is the probability of frost occurring within the $i$ th growing period corresponding to the $j$ th planting dekad; $C_{i j}$ is the number of years in which frost was obtained within the $i$ th growing period that started on the $j$ th planting dekad; $T_{i j}$ is the total number of years of the $i$ th growing period that started on the $j$ th planting dekad. 
TABLE 2: Climate stations in neighbouring provinces and Lesotho* used in the frost risk analysis.

\begin{tabular}{|c|c|c|c|}
\hline Station & Latitude & Longitude & Altitude (m) \\
\hline Aliwal North & -30.7167 & 26.7167 & 1348 \\
\hline Colesberg & -30.7000 & 25.1000 & 1328 \\
\hline Hazeldene & -28.0578 & 29.8907 & 1295 \\
\hline Hopetown & -29.6500 & 24.1833 & 1143 \\
\hline Kimberley & -28.8000 & 24.7667 & 1198 \\
\hline Ladysmith & -28.4615 & 29.6775 & 1191 \\
\hline Modder Rivier & -29.0500 & 24.6333 & 1120 \\
\hline Ottosdal & -26.9465 & 25.9713 & 1494 \\
\hline Oviston & -30.7000 & 25.7667 & 1294 \\
\hline Potchefstroom & -26.7333 & 27.0833 & 1345 \\
\hline Schweizer-Reneke & -27.1923 & 25.3176 & 1309 \\
\hline Vaal Harts & -27.9500 & 24.8333 & 1175 \\
\hline Vereeniging & -26.6833 & 27.9167 & 1440 \\
\hline Volksrust & -27.3667 & 29.8833 & 1652 \\
\hline Leribe $^{*}$ & -28.8800 & 28.0500 & 1740 \\
\hline Mafeteng ${ }^{*}$ & -29.8200 & 27.2500 & 1610 \\
\hline Mejametalana* & -29.3000 & 27.5000 & 1530 \\
\hline Mohale's Hoek ${ }^{*}$ & -30.1500 & 27.4700 & 1620 \\
\hline Oxbow ${ }^{*}$ & -28.7200 & 28.6200 & 2600 \\
\hline
\end{tabular}

TABLE 3: Geographical information of selected climate stations in the Free State Province used in the study.

\begin{tabular}{|c|c|c|c|c|c|}
\hline Station & Latitude & Longitude & Altitude (m) & Region & District \\
\hline Bethlehem & -28.1626 & 28.2953 & 1631 & Northeast & Thabo Mofutsanyane \\
\hline Bloemfontein & -28.9500 & 26.3333 & 1304 & Central & Motheo \\
\hline Bothaville & -27.4000 & 26.5000 & 1280 & North & Lejweleputswa \\
\hline Fauresmith & -29.7700 & 25.3200 & 1522 & Southwest & Xhariep \\
\hline Ficksburg & -28.8667 & 27.8500 & 1829 & East & Thabo Mofutsanyane \\
\hline Frankfort & -27.2667 & 28.5000 & 1502 & Northeast & Fezile Dabi \\
\hline Hertzogville & -28.2000 & 25.3000 & 1326 & Northwest & Lejweleputswa \\
\hline Virginia & -28.1000 & 26.8667 & 1335 & Northwest & Lejweleputswa \\
\hline Zastron & -30.3000 & 27.0830 & 1661 & Southeast & Xhariep \\
\hline
\end{tabular}

2.5. Temporal Variation of Frost Probabilities within Growing Periods. Temporal variation of frost occurrence in the Free State Province was investigated using selected but representative stations. The following nine stations from each of the five districts were selected to ensure fair distribution over the province covering all the agroclimatological regions (Table 3; Figure 2): Fezile Dabi district (Frankfort), Lejweleputswa district (Welkom, Virginia), Motheo district (Bloemfontein), Thabo Mofutsanyane district (Bethlehem, Ficksburg), and Xhariep district (Fauresmith, Zastron).

\section{Results and Discussion}

The results were broken down into two parts with the first section showing spatial distribution of frost probabilities and the second section showing temporal variability of frost from selected stations over the province.

3.1. Spatial Variation of Frost Probabilities within Growing Periods. Interpolated frost maps show high spatial variability of frost occurring within the growing periods (100-day, 120day, and 140-day crop) and planted in different periods from September to January.

During early planting (September to October), any crop cultivar is at risk of frost damage in the Free State. Planting any crop sensitive to frost in September is very risky especially in the first and second dekads where probabilities of frost occurrence exceeding $80 \%$ within the growing period are evident in most parts of the province (Figure 3). Planting in the first dekad of October results in moderate risk over patches in the central, eastern, southern, southeastern, and northeastern parts of the province where probability exceeding $40 \%$ is possible. The higher risks in these areas could be caused by a combination of altitude and topography in the east, altitude in the northern and central parts, and frontal systems that frequently pass through the southern part of the province during this time. Planting during the second dekad of October reduces the risk at these places to mostly less than $40 \%$ while in the third dekad the frost risk is mostly up to 


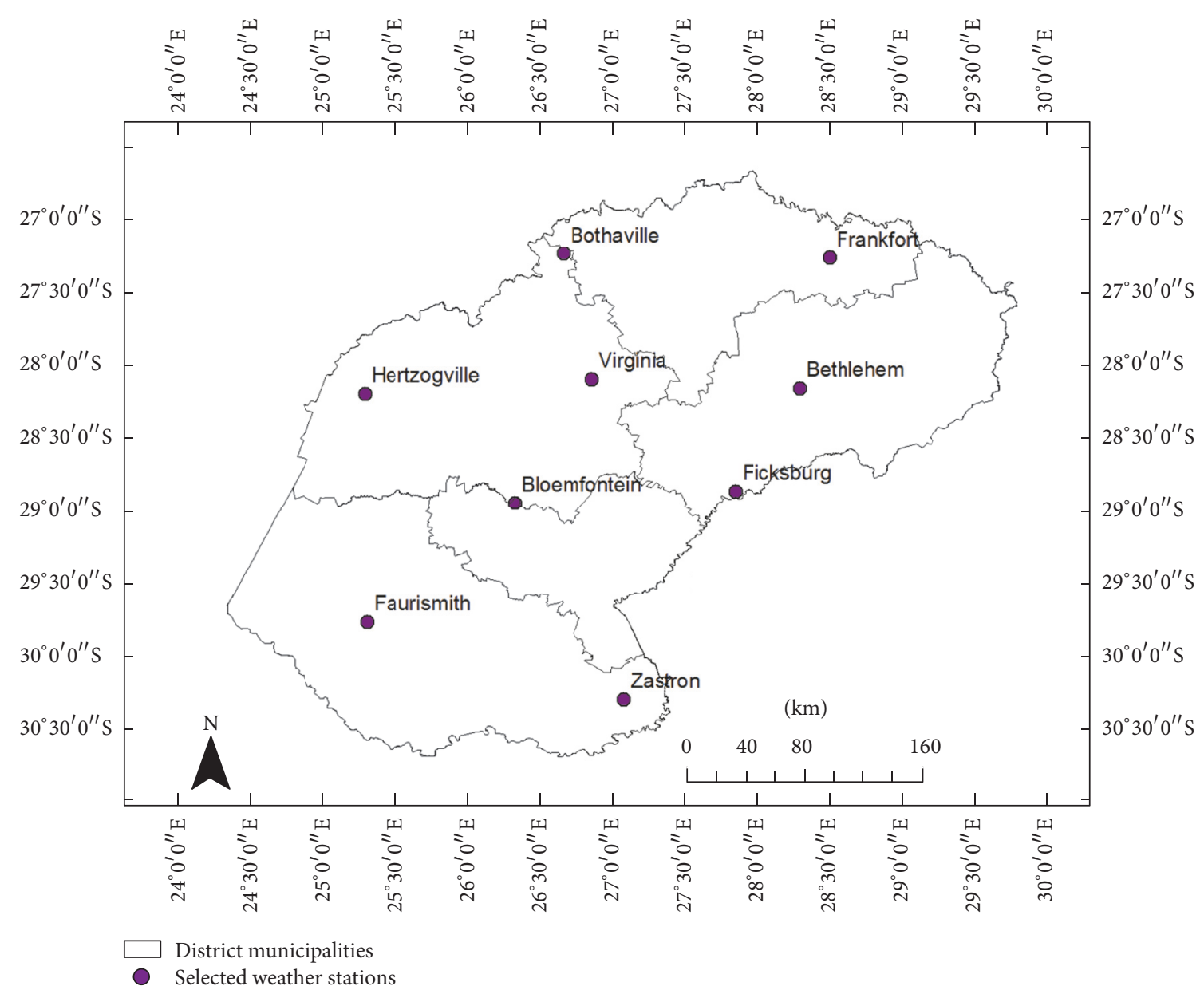

FIgURE 2: Geographical information of selected climate stations in the Free State Province used in the study.

$20 \%$. In the high frost risk regions, planting on or before the first dekad of October is not recommended because the likelihood of the crop failing due to frost damage is high. During the third dekad of October planting of any cultivar is subject to low frost risk; hence planting in this period is recommended. This is a good time to plant all cultivars so that they can avoid early onset of frost in autumn, particularly in the elevated eastern Free State region. The remainder of the province has less frost risk $(<10 \%)$ for all the October plantings. In these low frost risk areas the likelihood of frost damage during the growing period starting in October for all the three growing period lengths is minimal. During November planting period (first, second, and third dekads) the risk of frost damage over the Free State is minimal with most places having a less than $10 \%$ chance of frost within the growing periods.

Interpolated maps from December onwards are specific to the cultivar length since at these planting dates, the longer the growing period the higher the chances of the latter stages of the crop development coinciding with early frost occurring in March and April. If a farmer decides to plant a 100-day or 120-day cultivar during the first dekad of December, the crop growth and development are not likely to be affected by frost because of the low frost risk $(<10 \%)$ for almost the entire Free State Province (Figure 4). Furthermore, planting a relatively long season cultivar (140-day) will result in slightly increased risk of frost damage (21-40\%) mostly over some patches of the central, eastern, and southern Free State. When planting 100-day and 120-day cultivars in the second dekad of December, the crop is still expected to have no developmental hindrance caused by frost damage because of low risk of frost $(<10 \%)$ over nearly the entire province. However, the 140 -day crop planted on this dekad could be affected by autumn frost before it matures in most parts of the province with probabilities exceeding $40 \%$ being recorded. The $100-$ day cultivar planted in the last dekad of December is still expected to grow well in most parts of the province due to low frost risk $(<10 \%)$, but the 120 -day maize cultivar can be subjected to relatively higher frost risk (21-40\%) in autumn, especially over the eastern and southern parts. Altitude and topography play a crucial role in the eastern parts where daily minimum temperatures drop significantly in autumn. On the other hand, frost occurrence in the southern parts may be caused by frontal systems that start to traverse the region. When planting the 140-day maize cultivar at the end of December, the autumn frost risk increases drastically in this planting dekad over the entire province. The areas stretching from eastern to central Free State and to the south of the 


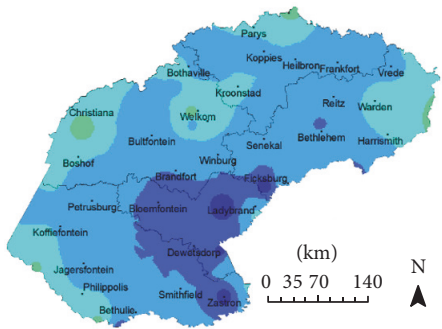

(a)

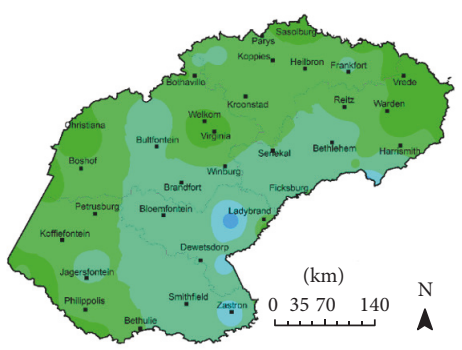

(d)

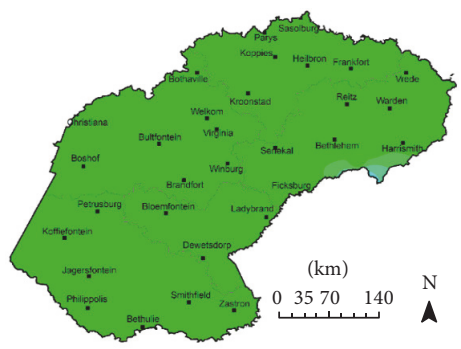

(g)

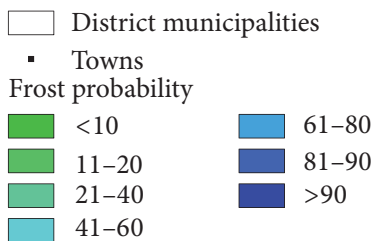

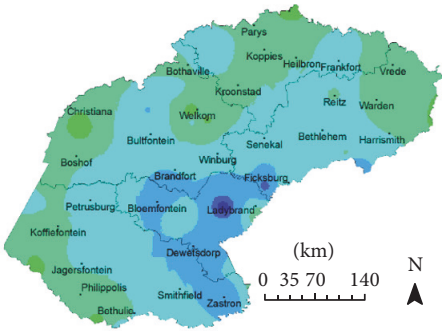

(b)

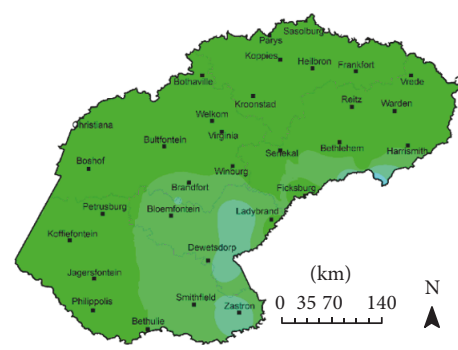

(e)

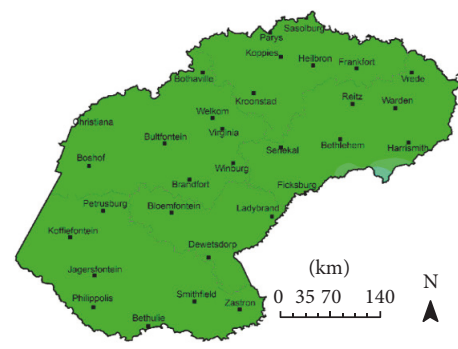

(h)

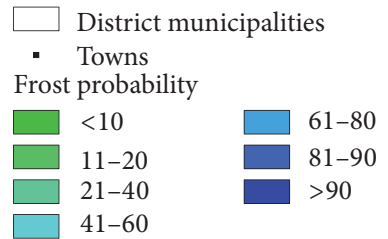

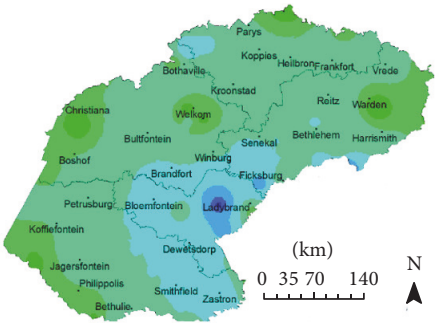

(c)

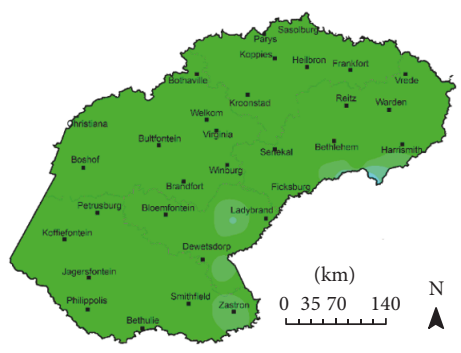

(f)

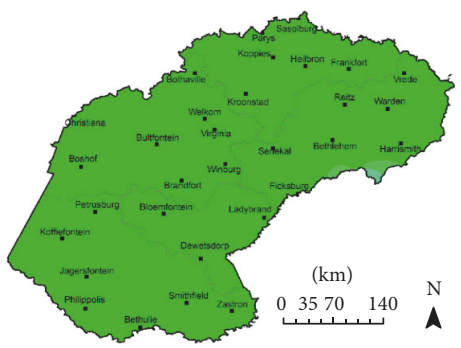

(i)

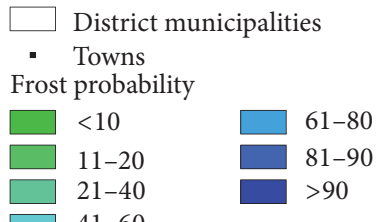

FIgURE 3: Probability of frost $\left(0^{\circ} \mathrm{C}\right)$ within growing period for planting in (a) September 1st dekad, (b) September 2nd dekad, (c) September 3rd dekad, (d) October 1st dekad, (e) October 2nd dekad, (f) October 3rd dekad, (g) November 1st dekad, (h) November 2nd dekad, and (i) November 3rd dekad.

province have between $61 \%$ and $80 \%$ chances of frost during the growing period starting in the last dekad of December. Some parts of the province have $41-60 \%$ chances of frost, with the northern parts and areas over the southwest having a less than $40 \%$ chance of frost occurrence.

Planting a 100-day maize cultivar during the first dekad of January is still expected to experience low risk of frost during the growing period for most parts of the Free State according to long-term climate data (Figure 5). But when planting a 120-day maize cultivar in this dekad there is relatively high frost risk damage in autumn over the eastern parts of the province with mostly up to a $60 \%$ chance of frost occurring within the growing period while other places still show moderate $(<40 \%)$ frost risk. Planting a 140 -day crop is not recommended in most parts of the province except in patches of the western and southwestern parts. In most parts of the province the frost risk probability ranges from $61 \%$ reaching maximum levels over $90 \%$. The province experiences moderate to low risk $(<20 \%)$ of frost for the growing period of the 100-day crop planted in the second dekad of January. As for the 120-day crop planted in the same dekad, high frost risk is evident in most parts. The 140-day crop is not suitable during the second dekad of January planting for the entire province because frost risk damage probability is in excess of $80 \%$. Planting a 100 -day crop cultivar during the third dekad of January shows frost risk damage chances between $21 \%$ and $40 \%$ for most parts of the province. Relatively high risk areas are still seen over the 


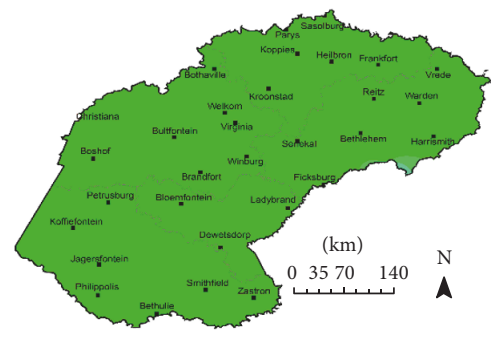

(a)

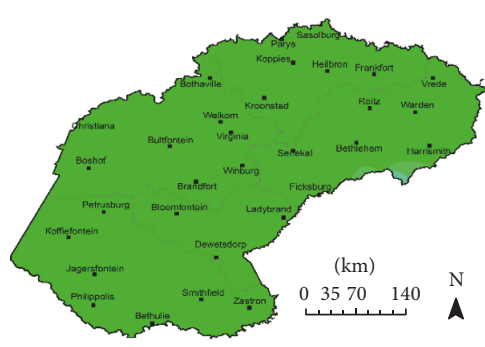

(d)

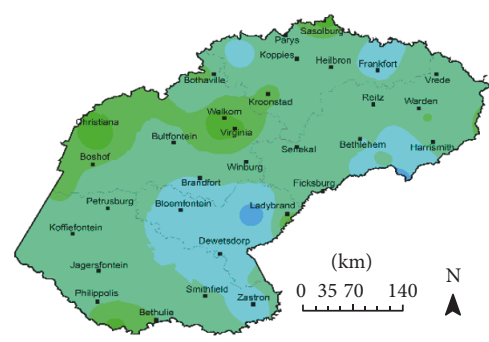

(g)

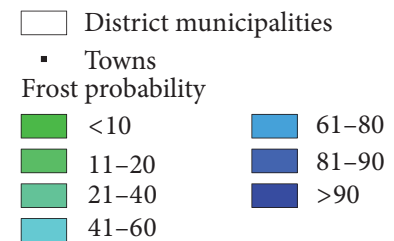

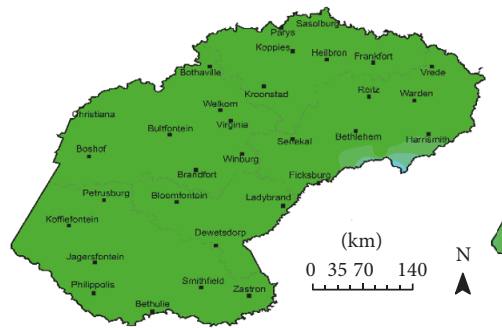

(b)

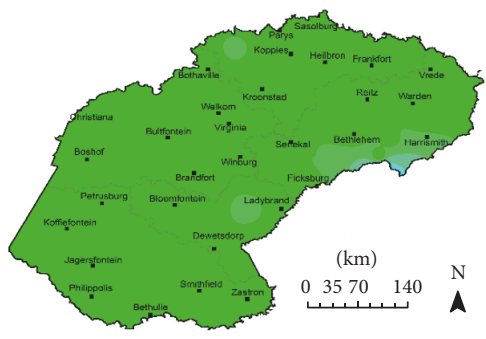

(e)

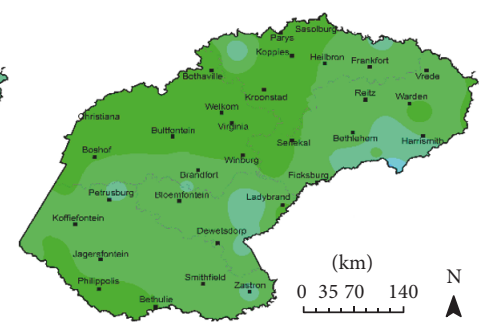

(h)

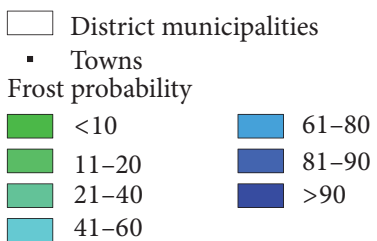

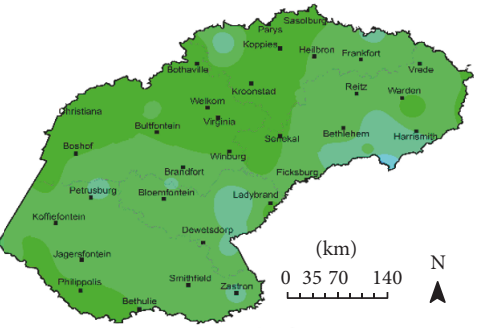

(c)

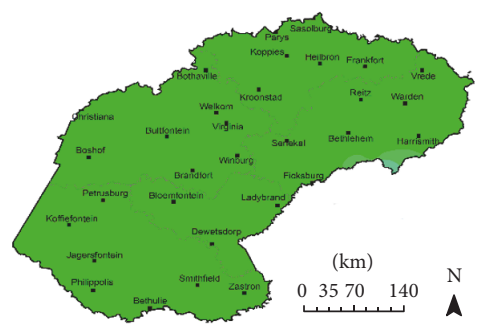

(f)

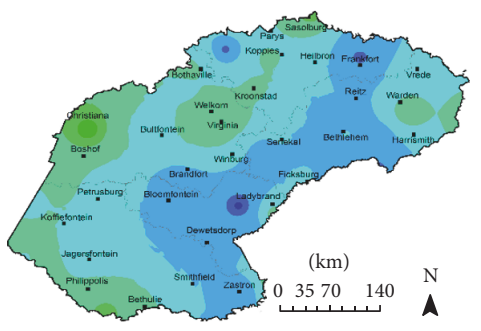

(i)

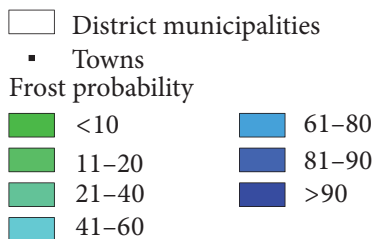

FIGURE 4: Probability of frost $\left(0^{\circ} \mathrm{C}\right)$ within growing period of (a) 100-day crop planted in December 1st dekad, (b) 120-day crop planted in December 1st dekad, (c) 140-day crop planted in December 1st dekad, (d) 100-day crop planted in December 2nd dekad, (e) 120-day crop planted in December 2nd dekad, (f) 140-day crop planted in December 2nd dekad, (g) 100-day crop planted in December 3rd dekad, (h) 120-day crop planted in December 3rd dekad, and (i) 140-day crop planted in December 3rd dekad.

eastern and southern parts with probability values reaching up to $80 \%$. The 120 -day crop cultivar planted in the last dekad of January shows frost risk probability exceeding $60 \%$ during its growing period for the entire province with few exceptions. The 140 -day crop has a more than $90 \%$ chance of being damaged by frost during the growing period starting in the third dekad of January.

\subsection{Temporal Variation of Frost Probabilities within Growing} Periods. Probability of frost occurring within the growing period is relatively high during the start of the rainy season in September (Figure 6). The probability is high in this planting period because in most places over the Free State there are still chances of the cessation of frost in spring with mostly $20 \%$ exceeding probability [8]. In most parts of the province (north, northeast, central, east, and southeast) relatively high probabilities of frost in excess of $50 \%$ in September are evident. Other areas over the northwest, west, and southwestern parts of the province experience low frost probabilities below 50\% when planting early. The values are high when planting during the first dekad of September and they decrease with time as the temperatures in the region increase. It can be depicted from Figure 6 that probabilities for planting short (100-day) or medium (120-day) or long (140-day) season crops are identical when planting in September and October, mainly because most of the frost 


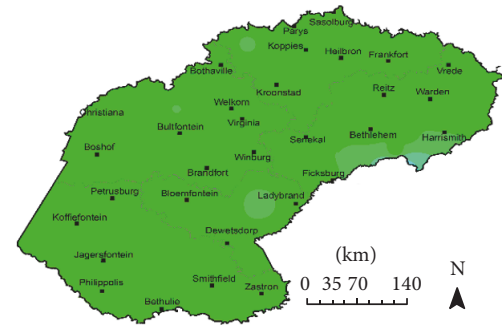

(a)

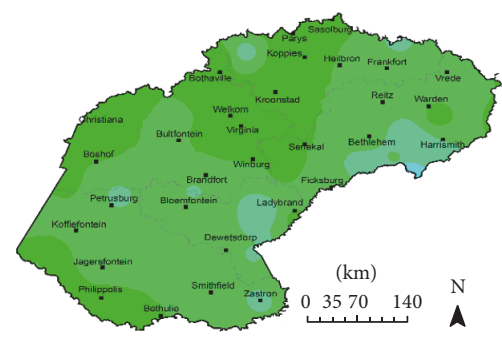

(d)

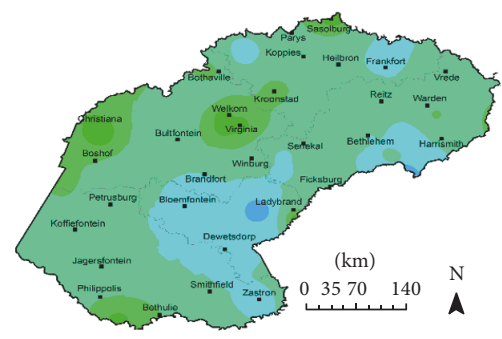

(g)

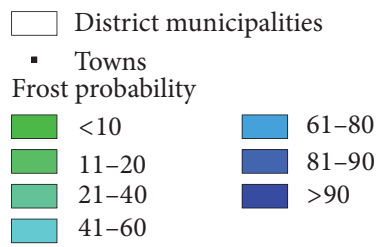

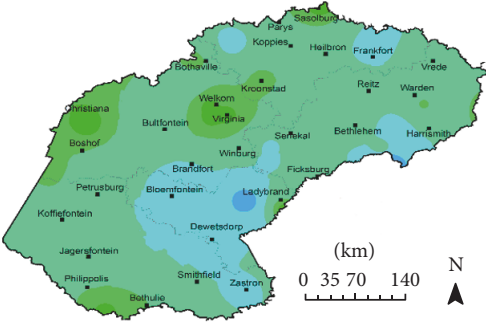

(b)

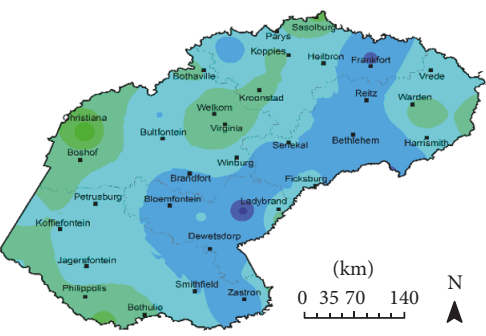

(e)

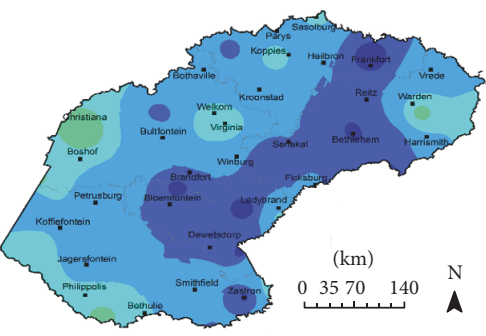

(h)

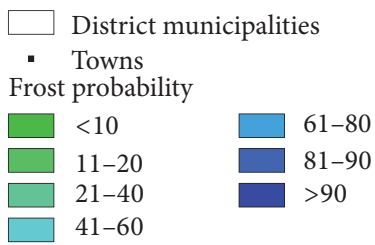

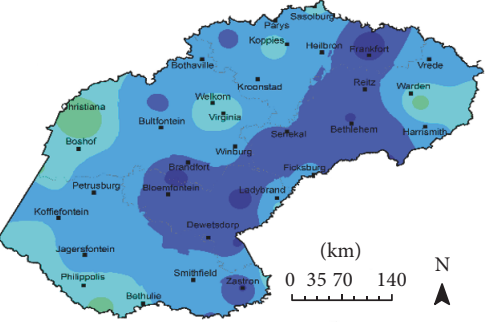

(c)

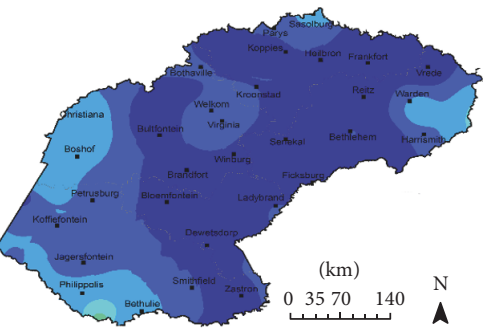

(f)

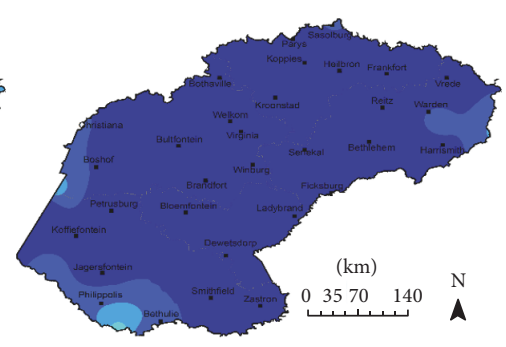

(i)

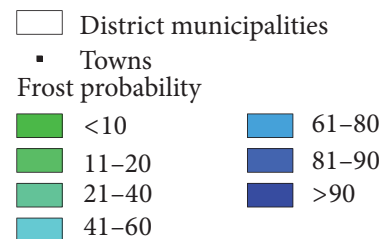

FIGURE 5: Probability of frost $\left(0^{\circ} \mathrm{C}\right.$ ) within growing period of (a) 100-day crop planted in January 1 st dekad, (b) 120 -day crop planted in January 1st dekad, (c) 140-day crop planted in January 1st dekad, (d) 100-day crop planted in January 2nd dekad, (e) 120-day crop planted in January 2nd dekad, (f) 140-day crop planted in January 2nd dekad, (g) 100-day crop planted in January 3rd dekad, (h) 120-day crop planted in January 3rd dekad, and (i) 140-day crop planted in January 3rd dekad.

occurrences are during the early stage of plant development. Thus, the length of the growing period is not the main factor during those planting periods. The lowest probabilities are mostly evident from the second dekad of October onwards to mostly January, depending on the locality and length of the growing period. The period of low frost probability is longer for 100-day growing period followed by 120 -day growing period while the 140-day growing period is shorter. At some stations like Bethlehem in the east, long and medium season crops can generally be planted over the three dekads (second dekad of October to first dekad of November) when the frost risk probability is lower than 20\%. In contrast, short season varieties can be planted until the third dekad of November as a result of a planting window of a month or more. Planting window for colder places like Bloemfontein in the central Free State, Ficksburg and Frankfort in the east, and Zastron in the south is also relatively short with only 60 days (October second dekad to December first dekad), 40 days (October second dekad to November second dekad), and 40 days (October third dekad to November third dekad), respectively. Other areas like Bothaville, Hertzogville, and Virginia in the northwestern and western parts have the longest planting windows for the 140-day crop over 90 days (September third dekad to December second dekad), 110 days (September second dekad to last dekad of December), and 90 days (last dekad of September to second dekad of 


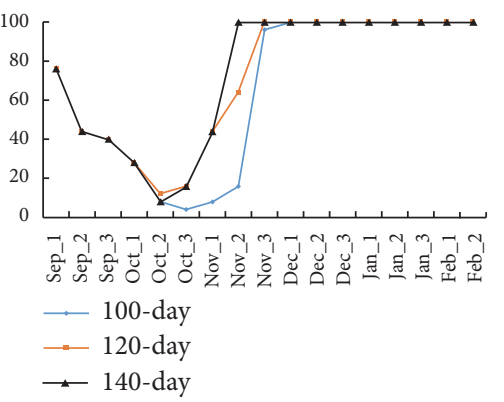

(a)

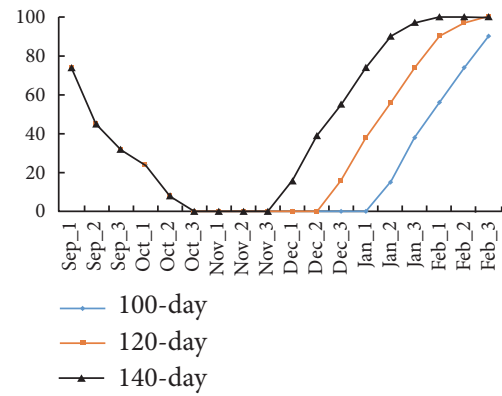

(d)

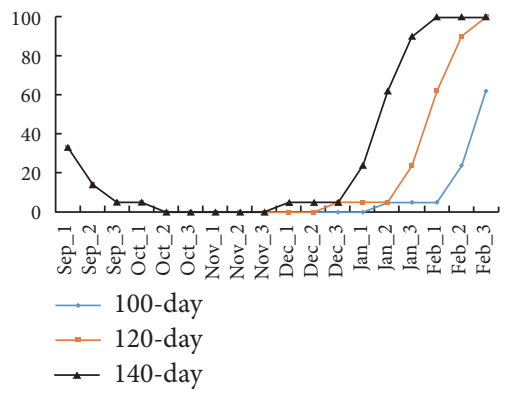

(g)

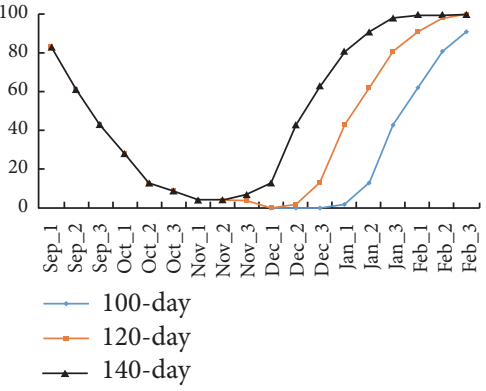

(b)

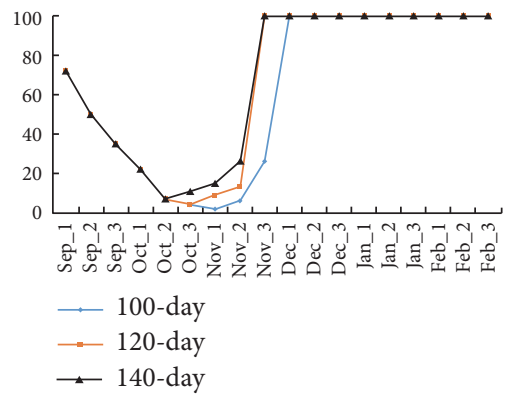

(e)

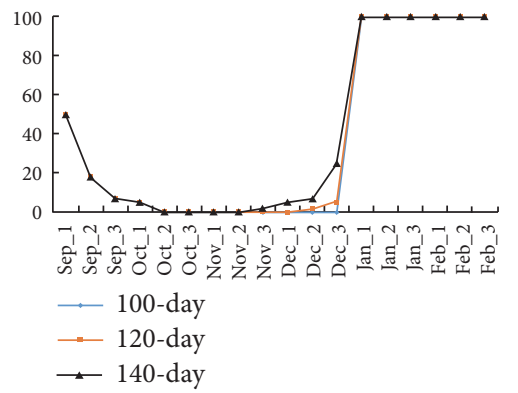

(h)

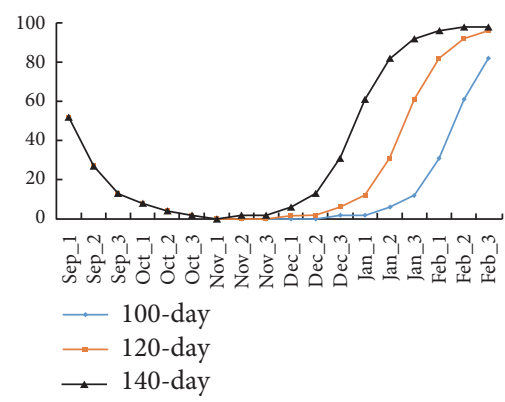

(c)

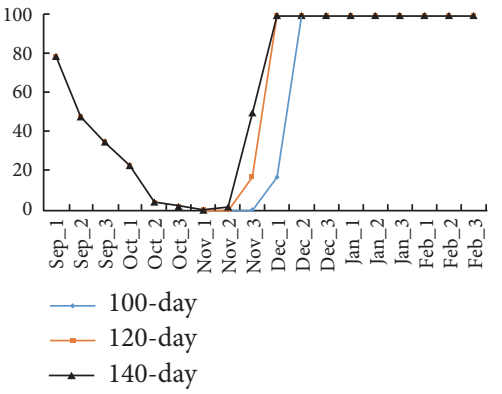

(f)

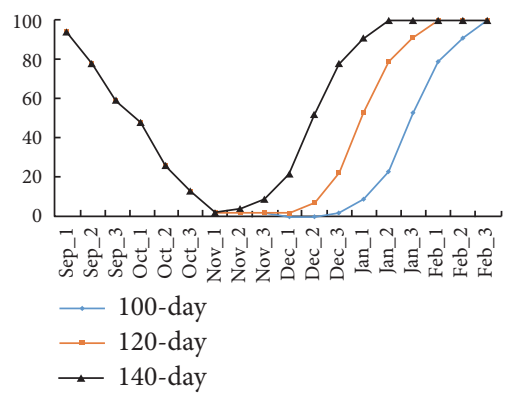

(i)

Figure 6: Temporal absolute frost probabilities during different planting periods and growing period length for (a) Bethlehem, (b) Bloemfontein, (c) Bothaville, (d) Fauresmith, (e) Ficksburg, (f) Frankfort, (g) Hertzogville, (h) Virginia, and (i) Zastron.

December), respectively. In these areas, planting of field crops like maize and sorghum can be subject to low frost risk in most parts of the growing period and thus they are suitable areas provided water requirements and other important environmental conditions of the crops are met [24]. The planting windows for a medium crop (120-day) are longer by 10-40 days, while for a short season crop (100-day) they are longer by 10-50 days as compared with that for a 140day crop.

\section{Further Discussion}

Agricultural production is highly affected by frost and cold temperatures in temperate climate areas [6] and this has an impact on food security in developing countries like South Africa. The results of this study show that high altitude areas in the Free State Province have high risk of frost, which is consistent with the findings of Tait and Zheng [17] and Laughlin and Kalma [25]. In the Free State, it can be depicted that early planting has considerable risk of frost in most areas in the province (Figures 2, 3, 4, and 6). Planting of annual crops during September and early October faces high risk of frost damage in the northeast, some parts of central Free State, and southwestern parts and hence delay in planting is recommended for these areas [26, 27]. In addition, the beginning of the rainy season (September to October) is characterised by high atmospheric water vapour deficits [21] and erratic rainfall [28]. In the case of fruit trees, it is advised that measures be taken to alleviate the impact of frost as it can be damaging to flowers and fruits [17]. For other frost sensitive crops like maize, early planting such as in October, September, and early November, any late frost has a damaging effect on crops at an early vegetative stage $[8,27]$. The maps for frost probability during different growing periods depict high frost risk during early plantings and the degree of frost severity is the same for all the growing periods, but when planting crops in December onwards, the length of the growing period determines the risk. Since areas with high frequency of frost are likely to experience major crop losses [2], areas over the northeastern parts of the province are 
highly vulnerable and frost sensitive crops have to be planted with caution. Crops with relatively short growing periods would be appropriate for minimizing the chances of crop failure. The longer the growing period the higher the chances of reaching high frost risk zone in the months of April, May, and June. Figures 3-6 also show high frost risk during the planting months of December onwards. These planting days subject crops to frost damage later on in their development stages. It is highly documented that the flowering and grainfilling stages of cereals are the most sensitive to frost and thus any frost incidence at these stages has a detrimental effect on productivity [12]. In fruit trees, early frost can also cause bacterium infection due to frost damage on growing shoots [17]. In the Free State Province, frost risk to crops is one of the main agroclimatological hazards having negative impacts on the production quantity and quality [26]. Combination of frost and other agroclimatological hazards makes cultivation of summer crops very risky [24]. It is recommended that growers be aware of the frost climatology and other agroclimatological risks in their areas so that they can minimize damage to their crops by avoiding susceptible crop growth stages coinciding with the period of greatest risks $[17,24,29]$.

There has been no estimate in South Africa of the monetary value of frost damage to crops but this could reach millions of South African Rand as there are widespread reports of frost damage countrywide every year [5, 27, 3036]. Annual frost losses to agricultural activities amount to over 120 million dollars in Australia [12] and frost damage exceeding 1 billion dollars annually was recorded in some years in the United States since 1980 to date [37].

\section{Conclusions}

Absolute probability of frost within the growing period showed suitability for the 100-day crop from planting in the second dekad of October until the first dekad of January with less than $10 \%$ chance of frost in the growing period. The 120-day crop showed low frost risk for planting from the second dekad of October to the last dekad of December, while planting the 140-day cultivar has low chance of frost risk damage from the second dekad of October to first dekad of December for most parts of the Free State Province. The appropriate planting days that minimize the frost risk for planting 100-day, 120-day, and 140-day cultivars are in November and the first 10 days of December in most places. As is to be expected, the risk increases with the increase in cultivar length with the 140-day cultivar having higher frequency of frost damage before it matures. Farmers are thus encouraged to take into consideration frost climatology when planning their agricultural activities.

\section{Conflicts of Interest}

The authors declare no conflicts of interest.

\section{Acknowledgments}

The study was funded by South Africa's Agricultural Research Council (ARC) and National Department of Agriculture,
Forestry and Fisheries. Special thanks are due to Dr. Fyfield of the ARC for editing the manuscript.

\section{References}

[1] K. Papagiannaki, K. Lagouvardos, V. Kotroni, and G. Papagiannakis, "Agricultural losses related to frost events: Use of the 850 $\mathrm{hPa}$ level temperature as an explanatory variable of the damage cost," Natural Hazards and Earth System Sciences, vol. 14, no. 9, pp. 2375-2381, 2014.

[2] Z. Wu, H. Lin, Y. Li, and Y. Tang, "Seasonal prediction of killingfrost frequency in south-central Canada during the cool/overwintering-crop growing season," Journal of Applied Meteorology and Climatology, vol. 52, no. 1, pp. 102-113, 2013.

[3] P. Matzneller, K.-P. Götz, and F.-M. Chmielewski, "Spring frost vulnerability of sweet cherries under controlled conditions," International Journal of Biometeorology, vol. 60, no. 1, pp. 123130, 2016

[4] M. J. Savage, "Estimation of frost occurrence and duration of frost for a short-grass surface," South African Journal of Plant and Soil, vol. 29, no. 3-4, pp. 173-181, 2012.

[5] K. Muller, T. G. O'Connor, and J. R. Henschel, "Impact of a severe frost event in 2014 on woody vegetation within the Nama-Karoo and semi-arid savanna biomes of South Africa," Journal of Arid Environments, vol. 133, pp. 112-121, 2016.

[6] C. M. Feldhake, "Forage frost protection potential of conifer silvopastures," Agricultural and Forest Meteorology, vol. 112, no. 2, pp. 123-130, 2002.

[7] E. Eccel, R. Rea, A. Caffarra, and A. Crisci, "Risk of spring frost to apple production under future climate scenarios: the role of phenological acclimation," International Journal of Biometeorology, vol. 53, no. 3, pp. 273-286, 2009.

[8] M. E. Moeletsi, M. Tongwane, and M. Tsubo, "The study of frost occurrence in free state province of South Africa," Advances in Meteorology, vol. 2016, Article ID 9586150, 9 pages, 2016.

[9] M. Teitel, U. M. Peiper, and Y. Zvieli, "Shading screens for frost protection," Agricultural and Forest Meteorology, vol. 81, no. 3-4, pp. 273-286, 1996.

[10] A. Bootsma and D. M. Brown, Freeze Protection Methods for Crops, FACTSHEET - ISNN, Ontario, Canada, 1985.

[11] T. Oztekin, "Analysis of frost damage risks in peach orchards around Tokat Turkey," International Journal of Engineering Science, vol. 2, no. 2, pp. 45-51, 2008.

[12] S. J. Crimp, B. Zheng, N. Khimashia et al., "Recent changes in southern Australian frost occurrence: Implications for wheat production risk," Crop and Pasture Science, vol. 67, no. 8, pp. 801-811, 2016.

[13] J. M. Whaley, E. J. M. Kirby, J. H. Spink, M. J. Foulkes, and D. L. Sparkes, "Frost damage to winter wheat in the UK: the effect of plant population density," European Journal of Agronomy, vol. 21, no. 1, pp. 105-115, 2004.

[14] P. R. Carter and O. B. Hesterman, "Handling corn damaged by Autumn frost," in National Corn Handbook, Climate Weather $\mathrm{NCH}-57$, p. 3, Cooperative Extension Service, Michigan State University, 1990.

[15] R. Sameshima, T. Hirota, and T. Hamasaki, "Mapping of FirstFrost Days and Risk of Forst Damage to Soybeans," Journal of Agricultural Meteorology, vol. 63, no. 1, pp. 25-32, 2007.

[16] F. M. Kelleher, N. M. Rollings, D. M. Poulton, and P. S. Cornish, "Temperature variation and frost risk in undulating cropland," in Proceedings of the 10th Australian Agronomy Conference, Hobart, Australia, 2001. 
[17] A. Tait and X. Zheng, "Mapping frost occurrence using satellite data," Journal of Applied Meteorology, vol. 42, no. 2, pp. 193-203, 2003.

[18] E. D. Cittadini, N. de Ridder, P. L. Peri, and H. van Keulen, "A method for assessing frost damage risk in sweet cherry orchards of South Patagonia," Agricultural and Forest Meteorology, vol. 141, no. 2-4, pp. 235-243, 2006.

[19] J. D. Kalma, G. F. Byrne, M. E. Johnson, and G. P. Laughlin, "Frost mapping in southern Victoria: An assessment of HCMM thermal imagery," Journal of Climatology, vol. 3, no. 1, pp. 1-19, 1983.

[20] C. Carbutt and T. J. Edwards, "The endemic and near-endemic angiosperms of the Drakensberg Alpine Centre," South African Journal of Botany, vol. 72, no. 1, pp. 105-132, 2006.

[21] M. I. Tongwane, M. J. Savage, M. Tsubo, and M. E. Moeletsi, "Seasonal variation of reference evapotranspiration and Priestley-Taylor coefficient in the eastern Free State, South Africa," Agricultural Water Management, vol. 187, pp. 122-130, 2017.

[22] M. E. Moeletsi and S. Walker, "Rainy season characteristics of the Free State Province of South Africa with reference to rainfed maize production," Water $S A$, vol. 38 , no. 5, pp. 775-782, 2012.

[23] Z. P. Shabalala and M. E. Moeletsi, Climate Data Patching Program, Agricultural Research Council - Institute for Soil, Climate and Water, Pretoriaw South Africa, 2015.

[24] M. E. Moeletsi and S. Walker, "A simple agroclimatic index to delineate suitable growing areas for rainfed maize production in the Free State Province of South Africa," Agricultural and Forest Meteorology, vol. 162-163, pp. 63-70, 2012.

[25] G. P. Laughlin and J. D. Kalma, "Frost hazard assessment from local weather and terrain data," Agricultural and Forest Meteorology, vol. 40, no. 1, pp. 1-16, 1987.

[26] M. E. Moeletsi, Agroclimatological risk assessment of rain-fed maize production for the Free State Province of South Africa [Ph.D. thesis], Department of Soil, Crop and Climate Sciences, University of the Free State, Bloemfontein, South Africa, 2010.

[27] M. E. Moeletsi, K. M. Nape, P. Magama et al., Mitigation and adaptation to climate variability and change in the Thabo Mofutsanyane district (Free State Province, South Africa): A multi-disciplinary approach through integrated crop-livestock system, Report for the Department of Agriculture, Forestry and Fisheries, Pretoria, South Africa, 2015.

[28] M. I. Tongwane and M. E. Moeletsi, "Intra-seasonal rainfall variability during the maize growing season in the northern lowlands of Lesotho," Theoretical and Applied Climatology, vol. 120, no. 3-4, pp. 575-585, 2015.

[29] Grain Research \& Development Corporation (GRDC). CerealsFrost Identification The back pocket guide. $2000 \mathrm{https} / / \mathrm{grdc}$ .com.au/ /media/ReFocus-media-library/Document/GRDCDocument-Store/Publications-Media-and-Communications/ Backpocket-Guides/Cereals-Frost-Identification-The-BackPocket-Guide-GRDC416.pdf.

[30] Morning Dew Farms. Large-scale frost damage hits crops 2015. http://www.mdf.co.za/index.php?option=com_content\&view= article\&id=107:large-scale-frost-damage-hits-crops\&catid=18: general\&Itemid $=290$.

[31] ENCA. Cape vineyards hit by 'devastating' black frost. 2016. https://www.enca.com/south-africa/cape-vineyards-hit-bydevastating\%E2\%80\%99-black-frost.
[32] Vinpro. Harvest report 2016. 2016. http://vinpro.co.za/Media/ Default/Downloads/VinPro_SA_Wine_Harvest_2016_Complete .pdf.

[33] Farmer's Weekly. Frost adds to Free State farmer woes. 2012 http://www.farmersweekly.co.za/agri-news/south-africa/frostadds-to-free-state-farmer-woes/amp/.

[34] Agriorbit. Tough times ahead for SA maize industry. 2016. http://agriorbit.com/tough-times-ahead-maize-industry/.

[35] A. Barnard, Barnard, A. Physiological changes in the wheat crop (Part 2). 2012. http://www.grainsa.co.za/physiological-changesin-the-wheat-crop-part-2.

[36] J. C. O. du Toit and T. G. O'Connor, "Minimum temperatures and frost at Grootfontein in the eastern Karoo, South Africa, over 98 years," Transactions of the Royal Society of South Africa, vol. 72, no. 1, pp. 39-46, 2017.

[37] NCDC. U.S. Billion-Dollar Weather \& Climate Disasters 19802016. 2016. https://www.ncdc.noaa.gov/billions/events.pdf. 

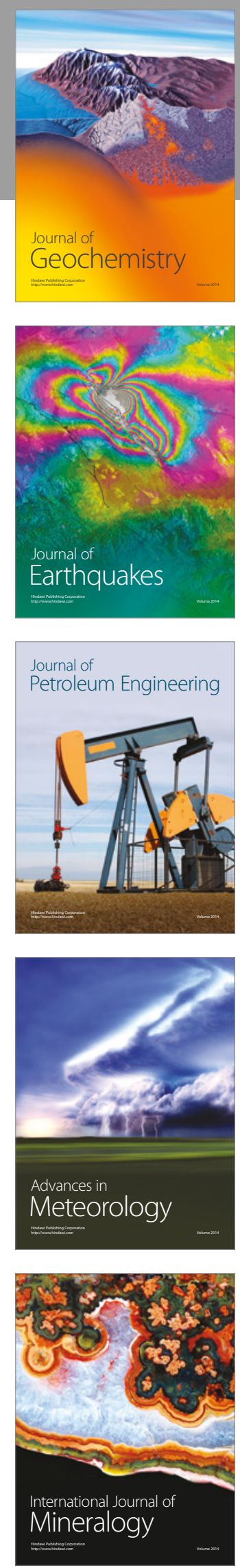
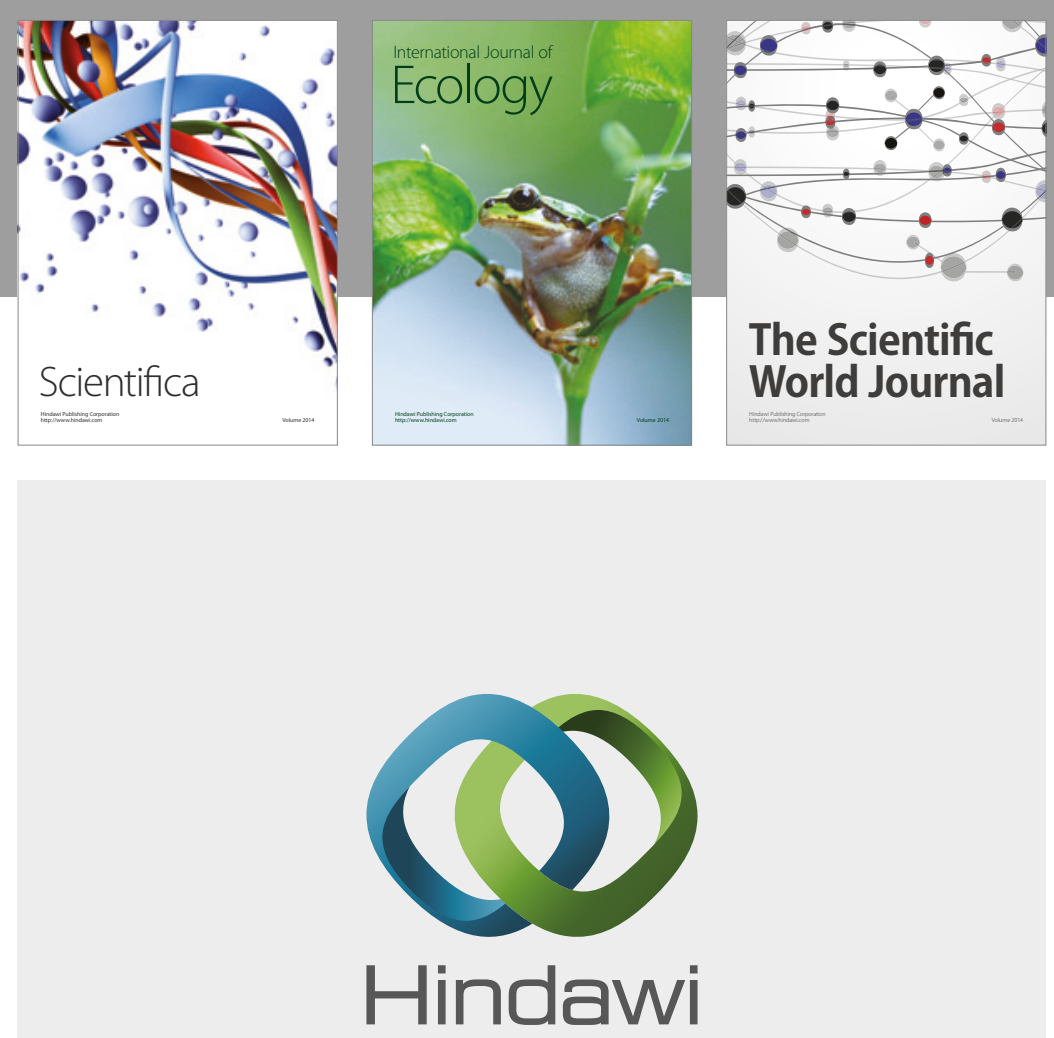

Submit your manuscripts at

https://www.hindawi.com
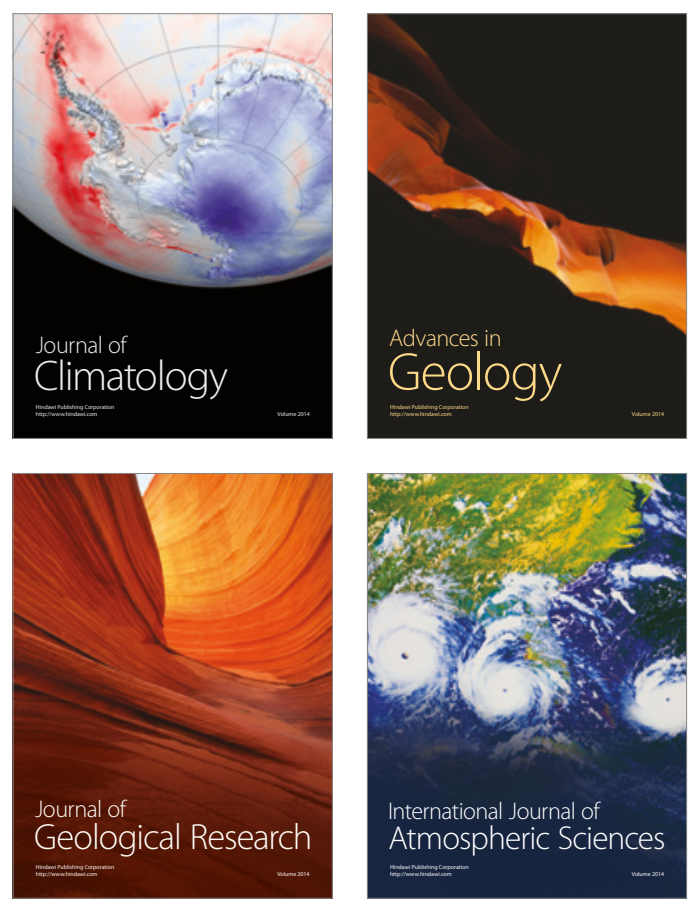

The Scientific

World Journal
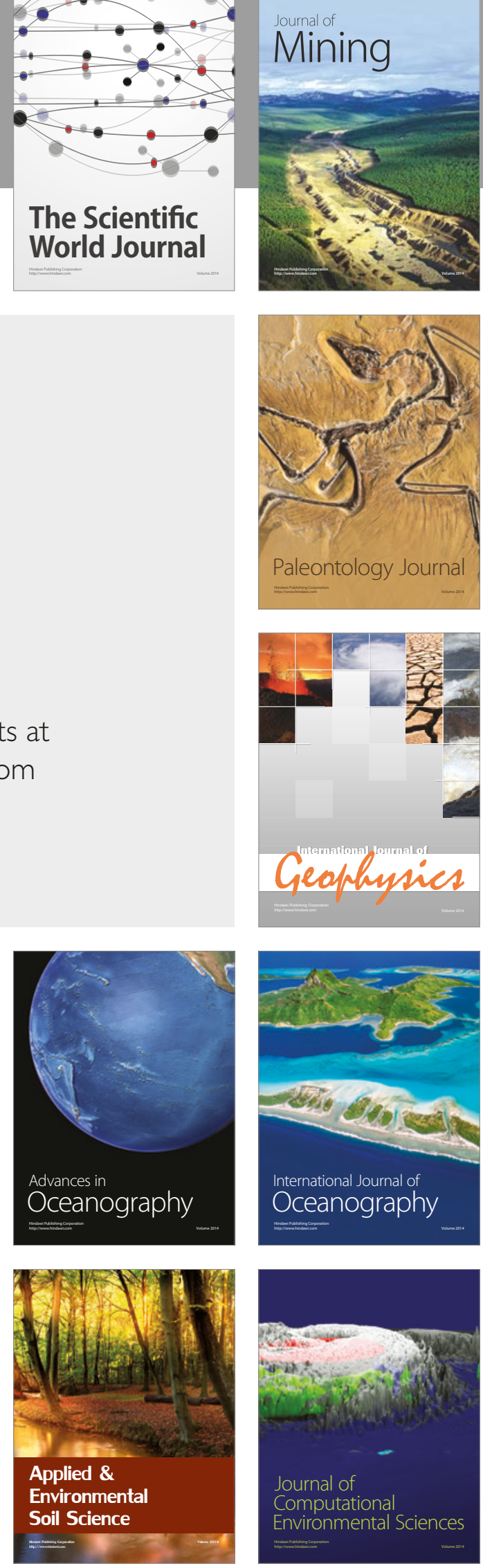